\section{Enhancing Consumer Horticulture's Millennial Outreach: Social Media, Retail, and Public Garden Perspectives}

\author{
Esther McGinnis ${ }^{1}$, Alicia Rihn ${ }^{2}$, Natalie Bumgarner ${ }^{3}$, \\ Sarada Krishnan ${ }^{4}$, Jourdan Cole ${ }^{5}$, Casey Sclar ${ }^{6}$, \\ and Hayk Khachatryan ${ }^{7}$
}

ADDITIONAL INDEX WORDs. botanical gardens, digital outreach, houseplants, plant parents, point-of-sale information, public gardens

SUMMARY. The millennial generation, born between 1981 and 1996 , is the largest demographic age group in the United States. This generation of plant enthusiasts has experienced financial setbacks; nevertheless, they collectively wield immense economic power. In 2018, this generation made one-quarter of all horticulture purchases. Consumer horticulture $(\mathrm{CH})$ is challenged to develop targeted programming and outreach methods to connect with this influential and informationhungry generation. To examine the possibilities, the $\mathrm{CH}$ and Master Gardener Professional Interest Group held a workshop on 23 July 2019, in Las Vegas, NV, at the American Society for Horticultural Science (ASHS) annual conference. The workshop first actively engaged participants to build points of connection by discussing nontraditional terminology that resonates with younger audiences. Suggested terminology included plant parent, plant enthusiast, plant babies, apartment-friendly, sustainable, and urban agriculture. After the opening discussion, three presentations explored innovative content, marketing and outreach in the areas of social media, retail promotions, and public gardens. The social media presentation focused on building a two-way partnership with millennials on Instagram that emphasized shared values of sustainability, local foods, and wellness. During the second presentation, the speaker highlighted retail point-of-sale promotions that appeal to younger audiences. The final presentation described creative programming used by botanical gardens to engage younger visitors. A facilitated discussion followed the presentations to identify and evaluate techniques and content that could be incorporated into $\mathrm{CH}$ research, teaching, and extension to reach and interact with new millennial audiences. Based on the workshop presentations and the facilitated discussions, the ASHS CH and Master Gardener Professional Interest Group concluded that more $\mathrm{CH}$ professionals should engage in social media outreach tailored to the needs and preferences of younger generations. To support this valuable outreach, research of consumer behavior and retail marketing should be encouraged to identify the preferred terminology and subject matter that appeal to millennials. Finally, $\mathrm{CH}$ can learn from and partner with public gardens as they implement multidisciplinary programming and exhibitions.

$\mathrm{T}$ The millennial generation (millennials) is the generation born after generation $\mathrm{X}$ (born between 1965 and 1980) (Dimrock, 2019). Although many institutions have attempted to determine the boundaries of this generation, the Pew Research Center is widely acknowledged to have set the generational birth range as 1981 to 1996 . In 2019 , millennials surpassed the baby boomer generation (born between 1946 and 1964) to become the largest demographic group in the United States (Fry, 2020). Approximately $39 \%$ of millennials between the ages of 25 to 37 years during the year 2019 had earned a bachelor's degree or higher, with women earning more
2020). Additionally, millennials have been strongly influenced by exposure to the Internet and technology while growing up (Dimrock, 2019).

Despite the lack of home ownership, many millennials are plant enthusiasts (Biggs, 2018) and a valuable source of potential customers for the horticulture industry. Millennials have created the term, "plant parent." A plant parent is defined as an individual who values and nurtures plants in a way similar to how other individuals value and nurture their children or pets (Urban Dictionary, 2020). In 2018, millennials were responsible for one-quarter of all horticulture purchases, and a large portion of these purchases were tropical houseplants (National Gardening Association, 2019). Between 2016 and 2018 , the sales of houseplants in the United States increased $\approx 50 \%$ to $\$ 1.7$ billion. Millennial men purchased $53 \%$ of houseplants, whereas millennial women purchased $47 \%$ (National Gardening Association, 2018). This trend toward indoor greenery is indicative of an indoor lifestyle. Because Americans spend $93 \%$ of their time in interior environments or vehicles, they crave a closer connection to nature (Garden Media Group, 2018).

Consumer horticulturists from university extension have long been considered a reliable information source for older generations, such as baby boomers and the silent generation. However, millennials are less likely to seek out extension consumer horticulturists for science-based plant information; instead, they favor social media, interior designers, and lifestyle influencers (Bilyj, 2018). Even during a time of high plant interest and new plant parents, extension $\mathrm{CH}$ is challenged to seize the opportunity to connect with a younger generation and expand its audience. The extension teaching and outreach methods that worked for baby boomers may be less effective for reaching a technology- and wellness-obsessed generation of millennials. To address the challenges of connecting to information-hungry millennials, the ASHS CH and Master Gardener Professional Interest Group organized a workshop at the 2019 ASHS annual conference. The objective was to explore outreach methodology used by three sectors outside of university extension: digital and social media, 
retail and marketing, and public gardens. Although the workshop focus was on millennials, youth outreach is also briefly discussed in the final section.

\section{Materials and methods}

On 23 July 2019, at the ASHS annual conference in Las Vegas, NV, the $\mathrm{CH}$ and Master Gardener Professional Interest Group organized and hosted a workshop entitled, "Reaching New Audiences in the 'Plant Parent' Generation.” Approximately 20 individuals with an interest and/or expertise in $\mathrm{CH}$ were in attendance and represented universities, extension, industry, and public gardens.

The workshop commenced with an opening discussion of the use of horticulture terminology. Different terminology resonates with younger generations compared with baby boomers and the silent generation (Dole, 2018). After the terminology discussion, three presentations discussed methods to reach millennial plant parents and the younger generation. Jourdan Cole, Account Executive for Garden Media Group, described the forging of digital connections with millennials. Dr. Alicia

$\overline{\text { Received for publication } 20 \text { July 2020. Accepted for }}$ publication 6 Oct. 2020

Published online 10 November 2020.

${ }^{1}$ North Dakota State University, Department of Plant Sciences, North Dakota State University Department 7670 , P.O. Box 6050, Fargo, ND 58108

${ }^{2}$ Agricultural \& Resource Economics, University of Tennessee, 321C Morgan Hall, 2621 Morgan Circle, Knoxville, TN 37996

${ }^{3}$ Plant Sciences Department, University of Tennessee, 2431 Joe Johnson Drive, 252 Ellington Plant Sciences, Knoxville, TN 37996

${ }^{4}$ Denver Botanic Gardens, 1007 York Street, Denver, CO 80206

${ }^{5}$ Garden Media Group, 520 West State Street, Kennett Square, PA 19348

${ }^{6}$ American Public Gardens Association, 351 Longwood Road, Kennett Square, PA 19348

${ }^{7}$ Food and Resource Economics Department and Mid-Florida Research and Education Center, University of Florida, 2725 South Binion Road, Apopka, FL 32703

This paper is based on the Workshop titled "Reaching New Audiences in the 'Plant Parent' Generation," presented on 23 July 2019, during the 2019 American Society of Horticultural Sciences annual conference in Las Vegas, NV.

E.M. is the corresponding author. E-mail: esther. mcginnis@ndsu.edu.

This is an open access article distributed under the CC BY-NC-ND license (https://creativecommons.org/ licenses/by-nc-nd/4.0/).

https://doi.org/10.21273/HORTTECH04697-20
Rihn, Assistant Professor, Agricultural \& Resource Economics, University of Tennessee, focused on millennial perceptions and reactions to retail promotions and point-of-sale (POS) information. During the third presentation, Dr. Casey Sclar, Executive Director for the American Public Gardens Association, illustrated creative outreach by public gardens to reach younger generations. After the presentations, a facilitated discussion was conducted to focus on application of the ideas presented throughout the workshop. The workshop organizers led a conversation that included the three presenters and an estimated $20 \mathrm{CH}$ professionals from university, extension, industry, and public gardens. The ideas that were generated are summarized in the facilitated discussion portion of this manuscript.

\section{Results \\ Workshop terminology discussion}

New, engaging terminology is essential to reaching millennial audiences because the existing horticulture terminology is not recognized by younger generations (Dole, 2018). Youth focus groups have previously identified that the terms "plantologist" and "plant specialist" are preferred over the traditional term "horticulturist." Using unfamiliar terminology with millennials may result in less receptivity to the message. During the facilitated discussion, the following were identified as traditional terms and concepts that are less likely to resonate with millennials: horticulture, ornamental horticulture, gardening, Master Gardener, landscape, yard, lawncare, green thumb, and propagation. In contrast, the following terms and concepts were identified as potentially millennial-friendly: plant enthusiast, plant parents, plant babies, apartmentfriendly, edible, organic, sustainable, local, green, urban agriculture, and succulent. More consumer behavior research is needed in this area to identify attractive terminology for millennials.

\section{Social media outreach}

Jourdan Cole, Account Executive for Garden Media Group, noted that $\mathrm{CH}$ cannot afford to ignore this influential group of plant parents and must consider millennial characteristics and their reliance on social media as part of a comprehensive marketing and branding strategy. The first step is to "befriend" [a social media term for sending a friend request (Cambridge Dictionary, 2020)] millennials and foster trust by capitalizing on social media platforms that draw them. Facebook (Facebook, Menlo Park, $\mathrm{CA}$ ) and YouTube (Google, Mountain View, CA) are the dominant platforms for individuals 50 years or older (Perrin and Anderson, 2019). In contrast, Instagram (Facebook, Menlo Park, CA) has become popular among millennials and younger generations, and it allows the sharing of photos, videos, and 24-h stories. Social media platforms like YouTube are popular with younger generations; however, due to time constraints, the workshop focused on Instagram. The visually rich nature of horticultural subjects complements this image-based social media platform (Barton et al., 2017).

To reach millennial plant parents, $\mathrm{CH}$ must use an Instagram strategy to make them "look good," "feel good," and "be entertained." Consumer horticulture can make them "look good" or enhance their social stature by providing trendy but informative plant content that millennials can share with their numerous followers. Content regarding tropical houseplants and succulents are incredibly popular, and sales have recently exploded (Biggs, 2018). Other horticulture-related areas include growing vegetables, edible foodscapes, canning, hydroponics, fruits, and hops (Humulus lupulus) (Drotleff, 2015). Topics related to environmentally friendly topics, such as composting/recycling, native plants, and connecting with nature, are also very popular (Garden Media Group, 2018).

Millennials desire plant information from reputable sources because they fear failure. Whitehouse (2015) has suggested that their intensely competitive upbringings make them fearful of taking risks and killing plants (Whitehouse, 2015). Therefore, $\mathrm{CH}$ is well-prepared to engage and educate in a way that makes millennial plant parents look good by demonstrating how to transplant tomato (Solanum lycopersicum) seedlings, prune a fruit tree, or divide 
a houseplant, thereby ensuring success for even the most risk-adverse millennial.

However, CH must do more than simply provide shareable content that is suitable for Instagram. In addition, $\mathrm{CH}$ must build its social media brand by actively engaging millennials by promptly answering posted questions, responding to comments, and asking for opinions and input (Barton et al., 2017). Millennial plant parents like to feel that they are partners with $\mathrm{CH}$ and that their opinions are heard, valued, and "liked." This engagement is consistent with the new participation economy that calls for a two-way personal relationship between the brand and millennial consumer (Fromm, 2013). In essence, the consumer becomes an active co-creator rather than simply an endpoint for information delivery.

Millennials want to "feel good"; this refers to their commitment to social and environmental causes globally and locally (Garden Media Group, 2018). Therefore, $\mathrm{CH}$ is strategically positioned to engage millennials in its programming because sustainability, ecosystem services, and wellness are primary objectives, as indicated by the National Initiative for Consumer Horticulture (NICH) statement of goals (National Initiative for Consumer Horticulture, 2017a). Natural areas of alignment include locally grown foods, nutrition, soil health, composting, organic production, pollinator gardens, water conservation and quality, and the use of health and wellness programming (Hall and Knuth, 2019). Although $\mathrm{CH}$ has always been engaged in conserving our natural environment and promoting wellness, it must find ways to incorporate these values more clearly into its brand identity. The NICH infographic, "PlantsDoThat Inside: Where We Live," is an Instagram-ready template for building brand identity around health and wellness (National Initiative for Consumer Horticulture, 2017b).

Finally, millennials want to "be entertained." Humor can be an instrumental tactic for social media (Barton et al., 2017). However, entertainment goes beyond humor to encompass a lifestyle that focuses on collecting meaningful experiences rather than expensive possessions (Morgan, 2019; Yue et al., 2016).
Millennials will pay for experiences or stories they can share on Instagram or other social media platforms (Garden Media Group, 2014). In addition, millennials with children are looking for gardening experiences to share with their children.

Although $\mathrm{CH}$ has much to offer millennial plant parents, it must do more to make them look good and feel good and to entertain them. By implementing an informative and participatory Instagram strategy, encouraging sustainability, and capitalizing on horticultural trends, $\mathrm{CH}$ can attract their attention and build a millennial-friendly brand. Unlike many social media influencers, $\mathrm{CH}$ can provide science-based recommendations to empower great plant parents.

\section{Retail marketing}

ShIFTING DEMOgRAPHICS AND marketing. Dr. Alicia Rihn, Assistant Professor, Agricultural \& Resource Economics, University of Tennessee, presented millennial marketing research. Traditionally, the core consumer of retail horticulture goods is 55 years or older, female, and from relatively higher-income households (National Gardening Association, 2013). However, between 2010 and 2012 , millennial spending on gardening-related purchases increased by 78\% (National Gardening Association, 2013). Millennials were particularly interested in dual-purpose plants (e.g., both edible and ornamental). The "grow your own food" movement likely contributed to this change.

Age is of particular interest to marketers because consumers within the same age groups tend to respond similarly to market stimuli. Target marketing occurs when consumers are grouped into homogenous segments with shared insights and needs and react comparably to marketing stimuli (Belch and Belch, 2009). Younger consumers are of interest to the horticulture industry because of their potential as an untapped market (National Gardening Association, 2013; Rihn et al., 2011; Zhao et al., 2016) and substantial spending power (Donnelly and Scaff, 2019). However, peer-reviewed marketing research of millennial horticulture consumers is scarce and, at times, conflicting. This section reviews recent studies on point-of-sale promotions and suggests avenues for future research.

EFFECTS OF RETAIL PROMOTIONS. The POS promotion is a key component of in-store marketing strategies, and it is used to promote products and services within the retail environment. Examples of POS promotions include advertisements, labels, logos, signs, displays, banners, shelf cards, and floor decals. These promotions are essential given the plethora of information that consumers are exposed to in the retail environment (Collart et al., 2013; Nordfält and Lange, 2013 ) and because $\approx 70 \%$ of purchasing decisions are made while in the store (Nielsen Company, 2016). As such, POS promotions attract consumers' attention and inform them about unique product attributes that may increase that product's value to the consumers and influence their choices (Ares et al., 2013; Rahimi, 2012).

In general, several eye-tracking studies have found that POS information is valued by horticultural consumers and aids garden centers in attracting more customers (Behe et al., 2014; Brand and Leonard, 2001; Khachatryan et al., 2018a; Stegelin, 2001). Behe et al. (2014) determined that consumers visually attend to POS information that is relevant to their personal preferences. For example, plant-oriented people were the quickest to focus on plant displays and viewed them for the longest duration. A similar pattern was observed for production method-oriented consumers (viewing sustainable production method signs above the plants) and priceoriented consumers (viewing price information). This information was used by the consumers when making plant selections, and there were no significant differences based on age groups.

Using a similar eye-tracking method, Khachatryan et al. (2018a) grouped participants by impulse purchasing tendencies and examined how they used POS promotions. They determined that impulsive consumers viewed POS information less and product displays more than less impulsive participants. Despite the reduced visual attention to the POS information, if an impulsive consumer viewed that information, then that consumer was more likely to 
purchase the plant than a less impulsive one. Conversely, viewing the display did not impact purchasing behavior. Age did not significantly impact these results, indicating that regardless of age, impulsive consumers behave similarly. Overall, POS promotions have great potential to influence millennial purchasing decisions through a variety of mechanisms.

Point-of-sale content. Recently, horticulture studies addressing POS information have shifted their content to emphasize valueadded information rather than plant growth requirements. Value-added information includes any information that generates value for the consumer. For example, sustainable production methods and local production of plants are value-added information reportedly valued by millennials (National Gardening Association, 2013; Yue et al., 2016). Often, this information is not readily available by visually inspecting the plant (i.e., credence attributes); therefore, the use of well-structured POS promotions is essential for informing consumers about the presence of that attribute. In turn, this information should heighten the consumer's desire for and value of that plant.

Many value-added POS promotions highlight environmentally friendly plant attributes and production methods. Rihn et al. (2015) investigated the likelihood of consumers to purchase indoor foliage plants. They found that organic production, in-state or domestic origins, and highly volatile organic compound removal (air-cleaning) attributes increased the purchase likelihood. Overall, younger consumers were swayed by environmentally friendly POS promotions and had higher purchase likelihood than their older counterparts. The results were supported by a second study, which found that consumer interests in organic production and in plants from closer origins were higher than their interests in plants grown using conventional methods and plants sourced from more distant locations (Rihn et al., 2016).

Khachatryan et al. (2018b) delved further into state marketing program logos (i.e., Fresh from Florida) and consumers' perceived benefits of locally grown plants. They determined that visual attention to the state marketing logo increased the purchase likelihood, and that increased awareness of the local production campaign reduced visual attention to the logo. Unexpectedly, older participants agreed more with the environmental- and economy-related benefits of local production than younger consumers. In this study, younger consumers were less likely to purchase the products, showing trends opposite those reported by Rihn et al. (2015). This discrepancy may be attributed to differences in the studies' designs or participants surveyed. For instance, Khachatryan et al. (2018b) used fruit-producing plants and Rihn et al. (2015) used indoor foliage plants. Both products are in the ornamental plant category but may be perceived differently by end consumers. Fruit-producing plants require more space and light to grow, whereas indoor foliage plants tend to be compact and flourish in indoor environments.

Using plant signs as the POS promotion, Khachatryan et al. (2017) investigated the influence of a pollinator-friendly attribute on consumer preferences for ornamental plants. The pollinator-friendly signage improved the purchase likelihood. Additionally, visual attention to the plant sign increased the purchase likelihood. Older consumers were more likely to purchase the plants, consistent with the results of Khachatryan et al. (2017) but counter to those of Rihn et al. (2015). The variance in preferences by age likely comes from the use of different products, research questions, and samples. Nonetheless, the studies highlight the need for more horticultural retail marketing research to understand millennials' POS preferences. Interestingly, men in the millennial consumer group have been identified as a driving force behind plant purchases (National Gardening Association, 2019). Future studies could delve further into gender differences within the millennial market to identify the best means of communicating with different groups of young consumers.

Finally, it is important to note that although POS information content is important, so is delivery. As indicated by the aforementioned literature, environmentally friendly production practices can be attributes that are important to younger consumers. As such, eco-labels are frequently used to communicate the environmentally friendly attributes of a product/service to the end consumer. In practice, however, ecolabels in garden centers are presented in many different formats (e.g., handwritten, text, logo, pictorial representation, etc.), which raises questions about the effects of the label format on behavior. Rihn et al. (2019) addressed this by investigating the influence of the eco-label format (text vs. logo) on consumers' visual attention and valuation of fruit plants. In general, they determined that logos captured more visual attention than text representations (e.g., the non-GMO logo vs. GMO-free text). Respondents were willing to pay premiums for plants with ecolabels than for those without, and the premium was amplified for those items displaying logos rather than text. Age did not significantly impact these results, implying that eco-label logos are the preferred delivery method for environmentally friendly POS information.

\section{Role of public gardens}

Dr. Casey Sclar, Executive Director for the American Public Gardens Association, reported innovative youth outreach methods used by public gardens. Beyond communicating with consumers via social media and in the retail environment, public gardens serve as an important touch point and information source for younger generations. Public gardens are well-positioned to address our society's disconnect from nature by becoming socially relevant to a wide variety of constituents through programming, outreach, and research (Krishnan and Novy, 2016). Dodd and Jones (2010) identified key areas that botanic gardens should address to become socially relevant: broadening audiences; meeting the needs of communities by enhancing relevance; education; local and global research that have socio-economic impact; active contribution to public and political debates about the environment; modeling sustainable behavior; and engaging in actively changing attitudes and behaviors.

The American Public Gardens Association (APGA) and Botanic Gardens Conservation International (BGCI) are two organizations that provide technical resources for public gardens to advance their social 
relevance. The mission of the APGA is to "advance public gardens as leaders, advocates and innovators," and their vision is "a world where public gardens are indispensable."

The APGA serves more than 600 member gardens in 24 nations, with more than 9300 professionals working in these gardens. The estimated combined operating revenue of public gardens is $\approx \$ 2.3$ billion, and they serve $\approx 120$ million visitors per year (estimate for 600 member gardens) (APGA, 2020). This attendance accounts for $\approx 90 \%$ of attendance at all professional league sports combined, which is 131 million. Globally, 3534 public gardens are listed in the Garden Search database of BGCI (BGCI, 2018). These gardens are geographically distributed across every inhabited continent and located in every major urban metropolis area as well as in rural areas (Krishnan et al., 2019). With more than 60,000 experts on horticulture, taxonomy, conservation, and public education globally, these capacities contribute to plant research, education, conservation action and policy, and community engagement with plants (Krishnan et al., 2019).

The scale and expertise of these two organizations provide tremendous opportunities for public gardens to engage with visitors by providing unforgettable experiences that connect people with nature. Public gardens serve all ages and all audiences and provide venues for the social, health, and healing aspects of life. Krishnan and Novy (2016) identified four major programmatic areas of public gardens - recreation, horticulture, plant research, and education and outreach. As important aesthetic, cultural, and scientific establishments, gardens contribute to the well-being of our society. With the challenges faced by society today, such as climate change, food insecurity, biodiversity loss, and others, we need to not only attract millennials to connect with nature but also train the younger generation to become stewards of nature and nature conservation. A few examples of how public gardens are achieving this are listed here.

EXHIBITIONS AND PROGRAMS. Annual exhibitions of art and temporary displays have become a major movement in public gardens. Through art and exhibitions, gardens connect to diversified audiences, growing garden memberships, and repeat visitations while also generating revenue (Krishnan and Novy, 2016). A few examples of seasonal exhibitions include the Chapungu: Custom and Legend, a Culture in Stone at the Fairchild Tropical Botanic Garden in Miami, FL, in 2012; the Chihuly glass exhibition at Denver Botanic Gardens in 2014; and the Brazilian Modern: The living art of Roberto Burle Marx at the New York Botanical Garden in 2019. A more permanent example is the Brazilian-theme garden at the Naples Botanical Garden in Florida that celebrates the landscape designs of the Brazilian native Roberto Burle Marx. The Chihuly exhibition at Denver brought more than 1.4 million visitors to the gardens in 2014 . These types of artistic and cultural displays attract diverse audiences who may not otherwise visit a public garden, providing opportunities for them to connect them with nature and become hooked.

Many gardens now offer foodrelated programming to reach millennials and those who subscribe to the "foodie" movement. Foodies are individuals with a keen interest in gourmet foods and the latest food trends (Merriam-Webster, 2020). A few examples that capitalize on the foodie movement include the Making Bitters with California Natives event at the University of California Botanical Garden in Berkeley; Bitters, Botany, and the Big Screen event at the Idaho Botanical Garden in collaboration with the Sierra Club; and the Garden Chef Demos at the Atlanta Botanical Garden.

The nation's capital, Washington, DC, attracts millions of tourists each year. Strategically located at the $\mathrm{Na}-$ tional Mall in downtown Washington, DC, the Smithsonian Gardens and the United States Botanical Garden (USBG) develop programming to engage tourists. In 2019, the Smithsonian Gardens, for the first time in its 47-year history, presented a campuswide exhibition called Habitat. This indoor/outdoor exhibition included 14 distinct exhibits across various Smithsonian museums exploring the central theme of "protecting habitats protects life." In 2019, the USBG, through their exhibition "Gardens Across America," showcased 21 public gardens from different regions of the country through vignettes created by each garden illustrating region-specific stories.

Audience. Several studies have shown that experiences at an early age with guidance from an adult who serves as a plant mentor can make a huge difference in how youth perceive, appreciate, and seek to scientifically understand plants later in life and can instill an interest in cultivating them (Allen, 2003; Wandersee and Schussler, 2001). Balding and Williams (2016) noted that cultural factors also have a significant role based on how a particular society or ethnic group values plants. For example, Native North American, Aboriginal Australian, and Maori cultural groups, to name a few, have strong bonds with plants. These authors suggested that we need to enable empathy with plants by emphasizing the similarities between plants and humans through direct experiences. To achieve this, approaches need to be developed that foster empathy toward and identification with plants through collaborations between botanical and conservation practitioners and social scientists (Balding and Williams, 2016).

The millennial and younger generations are much more diverse than all previous generations (Bialik and Fry, 2019), and they have an interest in interconnecting in an authentic fashion. To engage them, science and conservation-based aspects need to be blended in a meaningful way. The $\mathrm{NICH}$ can facilitate this connection through its goals to restore and protect natural resources (National Initiative for Consumer Horticulture, 2017a). Seed Your Future is an initiative of the ASHS and Longwood Gardens that has more than 150 endorsing partners promoting horticulture as a vital, viable, and vibrant career. The "Bloom" graphics created by the program targets younger audiences. Similarly, the Plant Heroes program by the APGA, in collaboration with the U.S. Department of Agriculture (USDA) Forest Service and the USDA Animal and Plant Health Inspection Service, is a plant protection awareness program targeting youth. Through comic strips, activity books, games, and field guides, it encourages young audiences to explore the "bad guys" threatening plants. 
Technology. Technology in the gardens is also very important to reaching younger audiences. Having youth serve as virtual role models can make a big impact on attracting their peer group. One example is the development of an app that can save the bees and pollinators that was created by 8 -year-old Kedar Narayan from Pennsylvania. He developed the app called Pollinator for a Pet, to help his community create pollinator-friendly gardens.

With the mission of recreating the connection between people and the amazing natural world around us, the PlantSnap app encourages citizen science through plant identification using high technology. On average, people take $\approx 350,000$ plant snaps (photos) every day using this app. Apps like this provide opportunities to link people to various aspects of botany and horticulture and connect to plants. It also encourages citizens to go out and explore which plants thrive in their neighborhood parks, public gardens, and natural areas, thus leading to them becoming more educated and better stewardship of plants and nature.

\section{Facilitated discussion}

Audience discussions followed the formal presentations, and several key themes integrated with the presentations were a part of the group dialogue. Participants noted the opportunities that exist to specifically target new audiences using social listening data that are available from a range of online tools and marketing companies. Social listening comprises an "automated, algorithm-based analysis of online conversations" (Westermann and Forthmann, 2020). It can be used to gain large-scale insight into how users view different brands and products as well as a deeper understanding of demographics and other aspects of the audience itself. As marketers gather and analyze data from social media users for retailers, the opportunity also exists for educators to tailor content to reach new and emerging audiences. These datasets not only provide insight into plants and horticultural areas of interest but also provide connections between plant topics and spending patterns or interest areas and hobbies; for example, there is a common overlap between groups of people with interests in plants and pets, and this overlap provides insight into the target audiences.

There is also currently a key need for extension and research personnel to deliver information and education that meets the millennial need for experiences. Examples from public gardens include "Bulbs and Bourbon" and "Arbeeretum" events that connect plants with other areas of interest to younger generations. $\mathrm{Al}$ though some of these events may be hosted by extension, there is also an opportunity and need to connect with other institutions, such as libraries or garden centers that already engage with these audiences by offering events such as plant nights. It is also clear that millennials are integrating a range of interests, such as plants and food; these areas can be a means of connecting horticulture and plants with foodie interests. Grilling events that connect herbs, vegetables, and other gardening products with food preparation and consumption as well as integrating pet and plant themes are examples of crossover programming. Outreach should be nimble enough to reach younger audiences where they are rather than requiring them to attend only events offered by the existing programming or be engaged with only a specific content area.

In addition to hosting public garden-inspired events and experiences, the $\mathrm{CH}$ and Master Gardener professional interest group specifically agreed to adopt Instagram-based programming as a cornerstone of millennial outreach. The Instagram social media platform requires little training and equipment compared to videobased platforms. Furthermore, the pictorial nature of $\mathrm{CH}$ is a good fit for Instagram. The group also concluded that it would support and encourage continued consumer behavior and marketing research to identify the preferred terminology and subject matter preferences of younger generations. This important research must form the foundation of $\mathrm{CH}$ youth outreach.

\section{Conclusions}

As $\mathrm{CH}$ researchers and extension personnel, the predominant model that we have been trained to use or use most often is the expert model. This model most likely meets the expectations of older generations.
However, this hierarchical delivery of content to an audience with little engagement or personal connection may be limiting our connection with younger generations. The ongoing interaction required to build trust and connections with younger audiences needs to become an integral element of how we engage and teach. Social media platforms provide the means and necessity to develop ongoing interactions that may raise the bar of our efforts and require a more focused effort on continued engagement to reach younger generations. Furthermore, it may be time for a paradigm shift in our educational content delivery. As younger generations interact with videos and social media in increasingly higher percentages, a larger proportion of professionals and institutions should be considering how we can move past the traditional print publication to remain effective and relevant. Technological delivery methods are rapidly evolving, and the content of $\mathrm{CH}$ programming is equally important. Building on horticultural marketing research from the Garden Media Group and from universities, $\mathrm{CH}$ can tailor educational programming content to millennials. This line of research suggests a promising avenue for identifying shared generational interests and values. Finally, interdisciplinary public garden programs and initiatives have demonstrated extraordinary nimbleness and creativity. Using the perspectives shared during this workshop, $\mathrm{CH}$ can rise to the challenge of developing new educational content and outreach methods to reach the plant parent generation.

\section{Literature cited}

Allen, W. 2003. Plant blindness. Bioscience 53(10):926, doi: 10.1641/00063568(2003)053[0926:PB]2.0.CO;2.

American Public Gardens Association. 2020. Gardens survey. 19 July 2020. <https://www.publicgardens.org/ benchmarking-studies>.

Ares, G., A. Gimenez, F. Bruzzone, L. Vidal, L. Antunez, and A. Maiche. 2013. Consumer visual processing of food labels: Results from an eye-tracking study. J. Sens. Stud. 28(2):138-153, doi: $10.1111 /$ joss.12031.

Balding, M. and K.J.H. Williams. 2016. Plant blindness and the implications for plant 
conservation. Conserv. Biol. 30(6):11921199, doi: 10.1111/cobi.12738.

Barton, E.T., E.A. Barton, S. Barton, C.R. Boyer, J. Brosnan, P. Hill, J. Hoyle, J. Reid, J. Seger, and E. Stafne. 2017. Using technology to enhance extension education and outreach. Hort Technology 27(2):177-186, doi: 10.21273/HORTTECH03608-16.

Behe, B.K, B. Campbell, H. Khachatryan, C.R. Hall, J.H. Dennis, P.T. Huddleston, and R.T. Fernandez. 2014. Incorporating eye tracking technology and conjoint analysis to better understand the green industry consumer. Hort Science 49(12):1550-1557, doi: 10.21273/HORTSCI.49.12.1550.

Belch, G.E. and M.A. Belch. 2009. Advertising and promotion: An integrated marketing communications perspective. 8th ed. McGraw-Hill/Irwin, New York, NY.

Bialik, K. and R. Fry. 2019. Millennial life: How young adulthood today compares with prior generations. 17 Dec. 2019. <https://www.pewsocialtrends.org/ essay/millennial-life-how-youngadulthood-today-compares-with-priorgenerations $/>$.

Biggs, C. 2018. Plant-loving millennials at home and at work. 17 Dec. 2019. <https://www.nytimes.com/2018/03/ $09 /$ realestate/plant-loving-millennialsat-home-and-at-work.html>.

Bilyj, B. 2018. Houseplant comeback. 17 Dec. 2019 . <https://www. greenhousemag.com/article/coverstory-houseplant-comeback-trendsmillennials-indoor-foliage-2019/>.

Botanic Gardens Conservation International. 2018. Garden search. 12 May 2020. <http:// www.bgci.org/garden_search.php>.

Brand, M.H. and R.L. Leonard. 2001. Consumer product and service preferences related to landscape retailing. HortScience 36(6):1111-1116, doi: 10.21273/HORTSCI.36.6.1111.

Cambridge Dictionary. 2020. Definition of befriend. 5 Oct. 2020. <https://dictionary. cambridge.org/us/dictionary/english/ befriend $>$.

Collart, A.J., M.A. Palma, and C.E. Carpio. 2013. Consumer response to point of purchase advertising for local brands. J. Agr. Econ. 45(2):229-242, doi: $10.22004 / \mathrm{ag}$.econ. 149105 .

Dimrock, M. 2019. Defining generations: Where millennials end and generation $\mathrm{Z}$ begins. 17 Dec. 2019. <https://www. pewresearch.org/fact-tank/2019/01/ $17 /$ where-millennials-end-andgeneration-z-begins $/>$.
Dodd, J. and C. Jones. 2010. Redefining the role of botanic gardens - Towards a new social purpose. Botanic Gardens Conservation Intl., Richmond, UK.

Dole, J.M. 2018. ASHS presidential address: What does the future hold? HortScience 53(11):1723-1726, doi: 10.21273/HORTSCI.53.11.1723b.

Donnelly, C. and R. Scaff. 2019. Who are the millennial shoppers? And what do they really want? 7 May 2019. <https://www. accenture.com/us-en/insight-outlookwho-are-millennial-shoppers-what-dothey-really-want-retail $>$.

Drotleff, L. 2015. Cultivate '15 town hall meeting: Not your grandma's garden. 17 Dec. 2019. <https://www. greenhousegrower.com/management/ cultivate 15-town-hall-meeting-not-yourgrandmas-garden $/>$.

Fromm, J. 2013. The "participation economy": Work with millennials just as you would market to them. 17 Dec. 2019. <https://www.franchising.com/ articles/the_participation_economy_ work_with_millennials_just_as_you_ would_market_to.html>.

Fry, R. 2017. 5 facts about millennial households. 17 Dec. 2019. <https:// www.pewresearch.org/fact-tank/2017/ $09 / 06 / 5$-facts-about-millennialhouseholds $/>$.

Fry, R. 2020. Millennials overtake Baby Boomers as America's largest generation. 27 Sept. 2020 . <https://www. pewresearch.org/fact-tank/2020/04/ $28 /$ millennials-overtake-baby-boomersas-americas-largest-generation $/>$.

Fry, R., J.S. Passel, and D. Cohn. 2020. A majority of young adults in the U.S. live with their parents for the first time since the Great Depression. 29 Sept. 2020. <https://www. pewresearch.org/fact-tank/2020/09/04/ a-majority-of-young-adults-in-the-u-s-livewith-their-parents-for-the-first-time-sincethe-great-depression $/>$.

Garden Media Group. 2014. How to market gardening to millennials. $17 \mathrm{Dec}$. 2019. <http://grow.gardenmediagroup. com/download-garden-medias-guideon-how-to-market-gardening-tomillennials->.

Garden Media Group. 2018. Garden trends report 2019: Rooted together. 17 Dec. 2019. <http://grow.gardenmediagroup. com/2019-garden-trends-report $>$.

Hall, C.R. and M.J. Knuth. 2019. An update of the literature supporting the well-being benefits of plants: Part 3 Social benefits. J. Environ. Hort. 37(4):136-142, doi: 10.24266/07382898-37.4.136.
Khachatryan, H., A. Rihn, B. Campbell, C. Yue, C. Hall, and B. Behe. 2017. Visual attention to eco-labels predicts consumer preferences for pollinator friendly plants. Sustainability 9(10):1743, doi: 103390/ su9101743.

Khachatryan, H., A. Rihn, B. Behe, C. Hall, B. Campbell, J. Dennis, and C. Yue. 2018a. Visual attention, buying impulsiveness, and consumer behavior. Mark. Lett. 29(1):23-35, doi: 10.1007/ s11002-018-9446-9.

Khachatryan, H., A. Rihn, B. Campbell, B. Behe, and C. Hall. 2018b. How do consumer perceptions of "local" production benefits influence their visual attention to state marketing programs? Agribusiness 34(2):390-406, doi: 10.1002/agr.21547.

Krishnan, S. and A. Novy. 2016. The role of botanic gardens in the twenty-first century. Perspect. Agr. Vet. Sci. Nutr. Nat. Resour. 11(23):1-10, doi: 10.1079/PAVSNNR201611023.

Krishnan, S., T. Moreau, J. Kuehny, A. Novy, S.L. Greene, and C.K. Khoury. 2019. Resetting the table for people and plants: Botanic gardens and research organizations collaborate to address food and agricultural plant blindness. Plants People Planet 1(3):157-163, doi: 10.1002/ ppp3.34.

Merriam-Webster. 2020. Definition of foodie. 5 Oct. 2020. <https://www. merriam-webster.com/dictionary/ foodie $>$.

Morgan, B. 2019. NOwnership, no problem: An updated look at why millennials value experiences over owning things. 17 Dec. 2019. <https://www. forbes.com/sites/blakemorgan/2019/ $01 / 02 /$ nownership-no-problem-anupdated-look-at-why-millennials-valueexperiences-over-owning-things / $\# 30 \mathrm{c} 7 \mathrm{c} 595522 \mathrm{f}>$.

National Gardening Association. 2013. The National Gardening Association's comprehensive study of consumer gardening practices, trends, and product sales. Natl. Gardening Assoc., Williston, VT.

National Gardening Association. 2018. National gardening survey. 5 Oct. 2020. <https://gardenresearch.com/view/ national-gardening-survey-2018edition $/>$.

National Gardening Association. 2019. National gardening survey. 17 Dec. 2019. <https://gardenresearch.com/nationalgardening-survey-2019-edition/>.

National Initiative for Consumer Horticulture. 2017a. Our goals. 17 Dec. 2019. <https://consumerhort.org/>. 
National Initiative for Consumer Horticulture. 2017b. Plants do that inside infographic: Where we live. 17 Dec. 2019. <https://consumerhort.org/nichreleases-new-series-free-infographicsplantsdothat-inside $/>$.

Nielsen Company. 2016. It's not just about the shelf: Creating the ideal in-store experience. 7 May 2019. <https://www. nielsen.com/us/en/insights/article/ $2016 /$ its-not-just-about-the-shelfcreating-the-ideal-in-store-experience $/>$.

Nordfält, J. and F. Lange. 2013. In-store demonstrations as a promotion tool. J. Retailing Consum. Serv. 20(1):20-25, doi: 10.1016/j.jretconser.2012.08.005.

Perrin, A. and M. Anderson. 2019. Share of U.S. adults using social media, including Facebook, is mostly unchanged since 2018. 17 Dec. 2019. <https:// www.pewresearch.org/fact-tank/2019/ 04/10/share-of-u-s-adults-using-socialmedia-including-facebook-is-mostlyunchanged-since-2018/>.

Rahimi, R. 2012. Investigating the effect of in-store print advertising on consumer's visual attention using eye-tracking technology. MS Thesis, Karlstad Univ., Karlstad, Sweden. 14 Oct. 2020. <http://www.divaportal.org/smash/record.jsf?pid = diva $2 \%$ 3 A571526\&dswid $=659>$.
Rihn, A., C. Yue, B. Behe, and C. Hall. 2011. Generations X and Y attitudes toward fresh flowers as gifts: Implications for the floral industry. HortScience 46(5):736743, doi: 10.21273/HORTSCI.46.5.736.

Rihn, A., H. Khachatryan, B. Campbell, B. Behe, and C. Hall. 2015. Consumer response to novel indoor foliage plant attributes: Evidence from a conjoint experiment and gaze analysis. HortScience 50(10):1524-1530, doi: 10.21273/ HORTSCI.50.10.1524.

Rihn, A., H. Khachatryan, B. Campbell, C. Hall, and B. Behe. 2016. Consumer preferences for organic production methods and origin promotions on ornamental plants: Evidence from eye tracking experiments. Agr. Econ. 47(6):599-608, doi: 10.1111 /agec.12258.

Rihn, A., X. Wei, and H. Khachatryan. 2019. Text vs. logo: Does eco-label format influence consumers' visual attention and willingness-to-pay for fruit plants? An experimental auction approach. J. Behav. Exp. Econ. 82:101452, doi: 101016/ j.socec.2019.101452.

Stegelin, F. 2001. Role of point-of-sale information on consumers' purchase decisions. Southern Nursery Assoc. Res. Conf. 46:536-538.

Urban Dictionary. 2020. Definition of plant parent. 5 Oct. 2020. <https:// www.urbandictionary.com/define.php? term $=$ plant $\% 20$ parent $>$.

Wandersee, J.H. and E. Schussler. 2001. Toward a theory of plant blindness. Plant Sci. Bull. 47(1):2-9.

Westermann, A. and J. Forthmann. 2020. Social listening: A potential game change in reputation management. How big data analysis can contribute to understanding stakeholders' views on organisations. Corporate Comm. doi: 10.1108/CCIJ01-2020-0028.

Whitehouse, S. 2015. Generation Y's reluctance to garden linked to fear of failure. 17 Dec. 2019. <https://www. greenhousegrower.com/management/ generation-ys-reluctance-to-gardenlinked-to-fear-of-failure $/>$.

Yue, C., S. Zhao, and A. Rihn. 2016. Marketing tactics to increase millennial floral purchases. 5 Oct. 2020. <https://endowment. org/wp-content/uploads/2017/01/ FMRF_MarketingMillennialsReport.pdfs.

Zhao, S., C. Yue, M.H. Meyer, and C.R. Hall. 2016. Factors affecting U.S. consumer expenditures of fresh flowers and potted plants. HortTechnology 26(4):484-492, doi: 10.21273/HORTTECH.26.4.484. 